Received: January 8, 2016

\title{
Adapting the Media and Technology Usage and Attitudes Scale to Turkish
}

\author{
Hasan Özgür ${ }^{1}$ \\ Trakya University
}

\begin{abstract}
Due to the requirement of a current, valid, and reliable assessment instrument for determining usage frequencies of technology-based media and the attitudes towards these, this study intends to determine the validity and reliability of the Media and Technology Usage and Attitudes Scale, developed by researchers from California State University, under the conditions of Turkey. After testing the scale's Turkish-version equivalence score, it was applied to 913 university students who were studying in various departments and grades. Confirmatory factor analysis was performed to examine the 15 factor structure of the scale. In order to determine the reliability of the scale, Cronbach's alpha-internal consistency coefficient, corrected itemtotal correlation, and significance of the differences between the average scores of the top and bottom $27 \%$ of participants were examined through the t-test. Cronbach's alpha values for the sub-factors of the scale varied between .71 and .89 , and the split-half test correlations related to the sub-factors varied between .71 and .86 . The results obtained from the t-test showed that all the differences between the item averages for the top and bottom $27 \%$ were significant, that the 60 -item scale was consistent with the structure of the original 15 factors, and that it conformed with the data.
\end{abstract}

\section{Keywords}

Media and technology usage $\bullet$ Attitude $\bullet$ Multitasking $\bullet$ Task switching $\bullet$ Scale adaptation

1 Correspondence to: Hasan Özgür (PhD), Department of Computer Education and Instructional Technologies, Faculty of Education, Trakya University, Edirne 22000 Turkey. Email: hasanozgur@trakya.edu.tr

Citation: Özgür, H. (2016). Adapting the Media and Technology Usage and Attitudes Scale to Turkish. Educational Sciences: Theory \& Practice, 16, 1711-1735. 
In the years before mobile technologies became a significant part of daily lives, the hours or minutes spent on computer activities (Kraut et al., 1998), on video games (Anderson, Gentile, \& Buckley, 2007; Green \& Bavelier, 2003; Subrahmanyam, Greenfield, Kraut, \& Gross, 2001), and on various combinations of these events (Media Matrix, 1999; Nielsen Media Research, 1999) were considered in determining the frequency of media and technology usage. Rideout, Foehr, Roberts, and Brodie (1999) focused on measuring time spent on daily activities such as watching TV and movies, listening to music, playing videogames, and listening to the radio to determine children and adolescents' frequency of media and technology usage. Along with the gradual spread of the Internet, the measurement of the usage frequency of Internet and affiliated technologies has started to gain importance. In this context, Kraut et al. (1998), in their study measuring the use of media and technology, had revealed that determining the weekly usage period of the Internet is a significant criterion in revealing the usage frequency of media and technology.

As the act of measuring media and technology use concerns stationary tools that don't involve mobile technologies, such as desktop and laptop computers or game consoles, it is said to have been easier compared to measuring the technological tools of today (Rosen, Whaling, Carrier, Cheever, \& Rokkum, 2013a). In fact, with the assistance of wireless networks, users today now can access the Internet, sending and receiving e-mails through technological mobile devices (mp3 players, tablets, smartphones, other wireless mobile devices) that don't require being used motionless, and they are able to perform all kinds of daily events through computers using online messaging tools anywhere and at anytime. The use of media and technological tools independent of time and space has made the measurement of these tools' usage frequency harder and more complex (Rosen et al., 2013a). International Data Corporation's research (IDC, 2013), which examined the usage frequency of current media and technological tools in which 7,446 individuals between the ages of 18 and 44 participated revealed that eight out of 10 adults and nine out of 10 adolescents started paying attention to their phones within 15 minutes of waking up. Another study has revealed that adults check their phones approximately 34 times a day for short periods less than 30 seconds. National research has revealed that $58 \%$ of smartphone users check their phones at least once every hour, and that $73 \%$ of them panic when they lose their phones. Other research performed in Turkey by Google (2013) has revealed that $76 \%$ of smartphone users don't want to leave their houses without getting their phones and that $42 \%$ of them would prefer to stop watching TV instead of giving up their smartphones. On the other hand, research performed in Japan by Kamibeppu and Sugiura (2005) related to mobile-phone usage and short messages revealed that more than half of the participants had felt insecure when their instant messages weren't answered and that this caused them anxiety. 


\section{Methods Related to Measuring Technology Usage}

Research in the literature on measuring technology usage generally mentions four different methods: (a) measurement on a daily basis or measurement of hours/minutes spent using (Junco, 2013, 2014; Rosen, Carrier, \& Cheever, 2013; Rosen et al., 2013a); (b) measurement of usage frequency at specific times (Brasel \& Gips, 2011; Burak, 2012; Lenhart, Purcell, Smith, \& Zickuhr, 2010; Thompson, 2013); (c) use of Likert-type measurement tools covering opinions such as definitely agree/definitely disagree for measuring attitudes (Jenkins-Guarnieri, Wright, \& Johnson, 2013a, 2013b); and (d) sharing or examining the experiences of participants at specific times (Judd \& Kennedy, 2010; Moreno, Jelenchick, Koff, \& Eikoff, 2012a; Wang \& Tchernev, 2012). In the literature, a study by Junco (2013), where the usage periods of media tools for the social networks, sending and receiving e-mails, and getting information were examined, made it necessary to question the validity of this method, even if the time assessment related to the use of technology and technological tools seemed like a valid and frequently used method. From the data obtained in his research through software that was uploaded onto the users' computers to measure the time used, Junco revealed that the correlation among the time-use stated by the participants was positive and significant (Facebook usage: Pearson's $\mathrm{r}=.587, p<.001$; email usage: Pearson's $r=.628, p<.001)$. However, a huge difference was observed between the time participants specified for individual use of each technology or technological tool and the time measured by the software. While the time participants stated for Facebook social network usage was approximately 149 minutes on a daily basis, the time measured by the software was identified as approximately 26 minutes; there were also great differences based on the usage time of other technologies and technological tools.

\section{Methods Related to Measuring Social Media Usage}

The increasing use of social websites day by day, especially of Facebook, has been subject to a variety of research, and many different methods have been used to determine this usage status (Judd, 2014; Lampe, Wohn, Vitak, Ellison, \& Wash, 2011; Mazman \& Usluel, 2010; Özgür, 2013; Ryan \& Xenos, 2011). While some researchers have applied the usage frequency of Facebook based on hours/minutes (Junco, 2012a, 2012b; Rosen et al., 2013; Trepte \& Reinecke, 2013) and others have used measurement tools questioning the number of friends on these networks through Likert-type scales (Hampton, Goulet, Rainie, \& Purcell, 2011; Jenkins-Guarnieri et al., 2013b; Junco, 2012a, 2012b, 2014; Kalpidou, Costin, \& Morris, 2011; McCord, Rodebaugh, \& Levinson, 2014; Rideout, Foehr, \& Roberts, 2010; Vitak et al., 2011), one can encounter research in the following years that questioned events performed on these social websites (Clayton, Psborne, Miller, \& Oberle, 2013; Ellison, Steinfield, \& Lampe 2011; Jenkins-Guarnieri et al., 2013a; Moore \& McElroy, 2012; Wang, Kosinski, Stillwell, \& Rust, 2014) that revealed different results related to the use of social networks through social network analysis (SNA) methods (Balduini et al., 2012; Golbeck, 2013; Yakushev \& Mityagin, 2014). 


\section{Methods Related to Measuring Multitasking and Technology Usage}

According to the definition that has gained the most recognition, the concept of multitasking was defined as the cognitive ability of an individual to fulfill more than one unrelated task at the same time (Benbunan-Fich, Adler, \& Mavlanova, 2011; Delbridge, 2000, p. 15; Rideout et al., 2010; Salvucci \& Taatgen, 2010). Some researchers in the literature prefer using the concept of task-switching instead of multitasking when the two tasks requiring simultaneous completion are on the same subject (Cades, Werner, Boehm-Davis, \& Arshad, 2010; Judd \& Kennedy, 2010; Monsell, 2003).

On the other hand, other researchers have defined the concept of multitasking as the simultaneous use of more than one multimedia (Internet, social media channels, smartphone, e-mail, online communication, computer, TV, videogame, etc.) while completing more than one task at the same time in consideration of the tools users prefer in task switching (Carrier, Cheever, Rosen, Benitez, \& Chang, 2009; Foehr, 2006; Jeong \& Fishbein, 2007; Papper, Holmes, \& Popovich, 2004; Wang \& Tchernev, 2012; Yuan, 2011).

In studies with students or working individuals on multitasking, individuals were revealed to frequently and instinctively multitask when the technology and technological tools being used were for reading/answering text messages or e-mails or for checking social websites (Burak, 2012; Judd \& Kennedy, 2010; Kessler, 2011; Kraushaar \& Novak, 2010; Rosen et al., 2013; Rosen et al., 2013b; Tindell \& Bohlander, 2012). In another research realized by Moreno et al. (2012b), messages were sent to participants at random times through instant messaging channels that asked the participants to read and answer these messages simultaneously while fulfilling the tasks assigned to them. As a result of that research, participants were seen to be involved in multitasking more than half the time they're online. Another study realized by D'heer, Courtois, and Paulussen (2012) revealed that about $75 \%$ of participants watch TV while surfing the Internet. These results are similar to those from Nielsen's (2013) research, which indicated that about half of tablet (43\%) and smartphone (46\%) users watched TV while using these.

In the research on high school and college students, participants are seen to multitask when technology and technological tools are mainly being used (Baron, 2008; Foehr, 2006). In another research by Junco and Cotten (2011) where 3,000 high school and college students participated, $97 \%$ of the participants were seen to deal with other computer tasks while messaging online on their computers and that 935 of the participants watched TV, made phone calls, or performed similar events while messaging online.

Foehr (2006) and Carrier et al. (2009) revealed that younger individuals who had encountered technology at an earlier age were able to fulfill more tasks within the same time frame. On the other hand, the multitasking performances of individuals who 
actively used digital technologies (using social networks and the Internet for longer periods) were seen more often compared to other individuals (Alloway \& Alloway, 2011; Judd, 2014; Zhong, Hardin, \& Sun, 2011). In a similar study, Hambrick, Oswald, Darowski, Rench, and Brou (2010) specified that playing video games positively affects individuals' multitasking performances and that multitasking is a learnable skill.

\section{Media and Technology Use of Teacher Candidates}

In the process of keeping pace with the fast and dynamic structure of the information era and of fulfilling the requirements of an information society, information and communication technologies have become an essential part of our lives. In the process of becoming an information society, significant duties fall on teachers to adopt relevant technologies and extend their uses (International Society for Technology in Education [ISTE], 2008). Along with listing the technology literacy competences of teachers regarding the use of information and communication technologies among the competences of teachers that are internationally accepted, the Ministry of National Education (Turkey, MoNE) also lists these among the performance indicators of teachers and emphasize its importance (ISTE, 2008; MoNE, 2013). On the other hand, as one of the primary objectives of the F@TIH Project, the most extensive project for integrating technology into education in Turkey, teachers and teacher candidates' requirement to be able to effectively use information and communication technologies in the education process has come up in order to raise technologically literate students.

Operations for the process of integrating technology into education have been attracting attention, especially in recent years with the increased acceleration both in Turkey and abroad for today's teacher candidates, so that the teachers of the future will be able to use information and communication technologies more effectively in their education process (Çuhadar, Bülbül, \& Ilgaz, 2013). When examining the literature regarding information and communication technologies and/or media usage of teacher candidates in this integration process, research has been observed to mainly be performed related to media literacy (Çepni, Palaz, \& Ablak, 2015; Çetin, 2015; Karaman, 2010; Sarsar \& Engin, 2015). Other research has been observed regarding the use of information and communication technologies mostly related to the use of technology in education (Demirli, 2013; Han, Eom, \& Shin, 2013; Jiménez \& O'Shanahan, 2016; Teo \& Noyes, 2014; Tondeur, van Braak, Siddiq, \& Scherer, 2016; Valtonen et al., 2015), acceptance of technology (İşçitürk \& Kabakçı Yurdakul, 2014; Teo, 2015), integration of technology in education (Aslan \& Zhu 2015; Lee \& Lee, 2014), techno-pedagogic content/field knowledge (Çoklar, 2014; Hao, 2016; Kaleli Y1lmaz, 2015; Kaya \& Dağ, 2013; Mouza \& Karchmer-Klein, 2013; Tokmak Sancar, Yelken Yanpar, \& Konokman Yavuz, 2013; Ursavaş, Şahin, \& Mcilroy, 2014), and techno-pedagogic competences (Çuhadar et al., 2013; Kabakçı Yurdakul, 2011). 
When examining literature related to the use of social media and other Web 2.0 tools by teacher candidates in Turkey, the use of these environment(s) and tools has been observed for educational purposes (Cakir, 2015; Hughes, Ko, Lim, \& Liu, 2015; Kahveci, 2015; Kuzu \& Akbulut, 2013; Nielsen, Moll, Farrell, McDaid, \& Hoban, 2013; Piotrowski, 2015; Sendurur, Sendurur, \& Yilmaz, 2015), and their effects on individuals' socio-psychological characteristics (Berigel, Kokoç, \& Karal, 2012; Çam \& İşbulan, 2012; Dindar \& Akbulut, 2014; Özgür, 2013) are mainly scrutinized. In research on determining multitasking preferences, no study in the literature where teacher candidates had been selected as the sample were encountered; much research examining the effect of multitasking on learning and recalling were encountered (Baran, 2013; Burak, 2012; Carrier, Rosen, Cheever, \& Lim, 2015; Dindar \& Akbulut, 2016; Hwang, Kim, \& Jeong, 2014; Junco \& Cotten, 2012; Lawson, 2013; Pashler, Kang, \& Ip, 2013; Ravizza, Hambrick, \& Fenn, 2014; Sana, Weston, \& Cepeda, 2013).

Despite the various methods and tools (Aydın \& Karaa, 2013; Burak, 2012; Holmes, Papper, Popovich, \& Bloxham, 2005; Moreno et al., 2012a; Ophir, Nass, \& Wagner, 2009; Papper et al., 2004; Poposki \& Oswald, 2010; Wang \& Tchernev, 2012; Yavuz, 2005) for measuring individuals' media and technology use, as well as their related attitudes, the impermissibility of mutual assessment with other measurement tools has been specified as the results of each research were found to have used their own methods and assessment tools (Rosen et al., 2013). Moreover, much of the research has been identified as insufficient on the point of measuring media and technology usage and measuring attitudes related to these usage conditions (Rosen et al., 2013). On the other hand, as many of the measurement tools (Carrier et al., 2009; Jeong \& Fishbein, 2007; Ophir et al., 2009; Poposki \& Oswald, 2010) used in previous years haven't included information on the use of new technologies, the need for assessing usage conditions of new technologies and technological tools has called for adapting the Media and Technology Usage and Attitude Scale (Rosen et al., 2013) to Turkish. Adapting this measurement tool to Turkish can be considered as contributing to the literature due to presenting a new assessment format in which individual technology usage and attitudes are measured on the basis of frequency instead of individual time spent while using various other technologies that generally don't reflect the true time spent. Because it helps reveal usage and opinions related to smartphones, music players, and video games, as well as computers, what it brings to Turkish culture is considered important. On the other hand, when examining research in the literature related to the use of social networks, each research has been observed to concentrate on different dimensions of social media usage but to not generate a solution for overall comparison of the obtained results. For this reason, a need is seen for a measurement tool that can perform all together the determination of the usage frequency of social networks, actions performed on social networks, and number of friends on these networks. In this context, this measurement tool, which has been 
adapted to Turkish culture, is considered able to eliminate this existing deficiency in the literature. The adapted measurement tool also includes items that intend to reveal individuals' attitudes related to multitasking preferences as well as positive and negative attitudes about technology. This study intends to perform validity and reliability tests for the scale in Turkey, as no current measurement tool exists or has been adapted for use in Turkey to determine multitasking preferences.

\section{Method}

In this study, scale-adaptation steps as specified by Hambleton and Patsula (1999) and Deniz (2007) were followed.

\section{Model of Research}

This study is a scale-adaptation study based on the survey method. The survey method involves studies that intend to collect data in order to determine specific features of a group (Büyüköztürk, Çakmak, Akgün, Karadeniz, \& Demirel, 2014).

\section{Study Group}

In Turkey, $13.2 \%$ of the 3,628,800 students studying for a bachelor's degree are Faculty of Education students (Council of Higher Education [CoHE], 2015). On the other hand, no study in the literature has been encountered within Turkey or abroad with the aim of determining the multitasking preferences of teacher candidates, who make up a large percentage of all bachelor-degree students. This condition has given rise to the need to study a sample consisting of teacher candidates. Towards this aim, this research has been carried out with 913 teacher candidates studying in various departments of the Faculty of Education at Trakya University. All teacher candidates studying at the faculty who could be reached were included in the research group in order to increase the study's external validity. A more extensive study group also increases the strength of the analysis models that are tested (MacCallum, Browne, \& Sugawara, 1996; Weston \& Gore, 2006). Of the teacher candidates who participated in the research, 89 (32.6\%) study in the Department of Social Sciences Education; 151 (16.5\%), in the Department of Elementary Education; 117 (12.8\%), in the Department of Preschool Education; 96 (10.5\%), in the Department of Science Education; 102 $(11.2 \%)$, in the Department of Foreign Language Education; $167(18.3 \%)$, in the Department of Mentally Disabled Education; 147 (16.1\%), in the Department of Computer and Instructional Technologies Education; and 44 (4.8\%), in the Department of Fine Arts Education. Of the participants, who ranged in age between 18 and 22 (average age $=20.3), 615(53 \%)$ are female and $298(32.6 \%)$ are male. 


\section{Data Collection Tool}

The original name of the scale, developed in English by Rosen et al. (2013) for determining media and technology usage and attitudes, is the Media and Technology Usage and Attitudes Scale. The purpose of the formation of the scale is to reveal usage frequency through technological tools (smartphone, computer, TV, etc.) where media and technology are extensively used to determine the frequency of performed actions, such as mobile phone, TV, music listening, and videogame play usage in addition to computer usage, and to reveal attitudes towards media and technology usage.

The scale's original form, which consists of 68 items in total, was revealed to have 50 items aimed at determining media and technology usage levels and 18 items for determining attitudes. Media and technology usage levels were determined to consist of 11 factors and 44 items as a result of statistical analyses. The section determined to be on attitudes is formed of 15 sub-factors and 60 items in total, of which four factors and 16 items are relevant to the use of technology. Eleven sub-factors for determining the state of media and technology usage are listed as follows: Smartphone usage (nine items); general social media usage (nine items); and Internet searching, e-mailing, and media sharing (four items). Text messaging (SMS) and video gaming sub-factors for the scale consist of three items; online friendships, social media friendships, phone calling, and television viewing sub-factors each consist of two items. The last four sub-factors for determining attitudes related to media and technology usage are positive attitudes toward technology (six items), anxiety of being without technology/ technology dependency(three items), negative attitudes towards technology (three items), and multitasking preferences (four items, one reverse scored). The internal consistency of each sub-dimension of the scale was determined using Cronbach's alpha reliability coefficient, and these coefficients for the fifteen factors in total were found to be between .61 and .93. Exploratory factor analysis (EFA) was used for the validity of the structure. As a result of the EFA applied to the scale (originally consisting of 68 items), the scale came to consist of 11 factors and four items for measuring media and technology usage and four factors and 16 items measuring attitudes by removing some items that negatively affected validity (eight items). As a result of EFA, which was performed to reveal the original form of the scale, the percentage explaining total variance through the 11 factors related to determining media and technology usage levels was found to be $68 \%$ (smartphone usage, $11.94 \%$; general social media usage, 11.61\%; Internet searching. 7.15\%; e-mailing, 6.94\%; media sharing, 5.81\%; text messaging [SMS], 5.56\%; video gaming, 4.69\%; online friendships, 4.23\%; social media friendships, 3.69\%; phone calling, 3.35\%; and television viewing, 3.07\%). The percentage explaining the total variance through the four factors measuring attitudes related to media and technology usage was found to be $66.13 \%$. 


\section{Adaptation Process of the Scale}

In adapting the scale, adhering to the theoretical bases on which the scale relies is very important. Thus, minimizing the differences between the original scale and the adapted scale is necessary. First, making the required translations for the items in the scale meaningfully into the translated language and forming it as per the social and personal norms of the individuals using this language are the bases of adapting a scale to a new culture (Aksayan \& Gözüm, 2002; Öner, 1987). Next in the process of adaptation, steps are required for following up with a series of semantic, cultural, and statistical operations, such as inspecting the scale's psychometric features and item equivalence. Initially, getting permission to adapt the scale for use constitutes the ethical grounds of the adaptation process (Baş, 2006; Hambleton, Merenda, \& Spielberger, 2005; Öner, 1987; Savaşır, 1994). In this context, despite the researchers determining that the scale may be used without getting any permission and without paying any fee, they contacted Dr. Larry Rosen by e-mail anyway before the start of the adaptation process and received the pertinent permission to adapt it to Turkish using the original form. The following steps were then followed.

\section{Adaptation of Language}

This phase, which determined the translation equivalency and items, covers the translation process from source language to target language, and constitutes the most important aspect of the adaptation (Aksayan \& Gözüm, 2002). Thus, the translation of the scale from English to Turkish was performed by three researchers with good knowledge of the target and source languages, with good command of the relevant subject, and with experience in both cultures independent from each other. After completing the translation, the reverse-translation method (from among the judgmental methods) was used in order to test the equivalence of the words and phrases obtained from the draft form with the original scale. The translation that had been made was translated again to English by three different specialists working in the department of foreign language education and then checked by specialists in the field. The semantic shifts that arose and items that were considered to be contradictory were corrected by the researcher and the three specialists. Then the translation was submitted to three lecturers specialized in Turkish in order to get their opinion and check the translation in terms of grammar. In the following phase, the completed scale in Turkish was applied to 120 students not included in the study who were studying in the English Teaching Program of Trakya University in order to examine its linguistic equivalence. Personal interviews were then performed with 30 randomly selected students regarding the items of the scale in order to test its understandability and readability. Thus, the scale reached its final form. 


\section{Findings}

\section{Findings Related to Linguistic Equivalence}

The name of the scale, which had been adapted to Turkish, is called the Media and Technology Usage and Attitudes Scale in consideration of its content. The first nine factors of the scale, consisting of 40 items (smartphone usage, general social media usage, Internet searching, e-mailing, media sharing, text messaging [SMS], video gaming, phone calling, and television viewing) was made into a 10-point Likert structure (never-always). The $10^{\text {th }}$ and $11^{\text {th }}$ sub-factors (online friendships and social media friendships) that covered four items of the scale were applied in a 9-point Likert structure (from 0 to 751 friendships or more). The $12^{\text {th }}$ through $15^{\text {th }}$ sub-factors of the

\begin{tabular}{|c|c|c|c|c|}
\hline $\begin{array}{l}\text { Table } 1 \\
\text { Linguistic Equivalence Findings } o\end{array}$ & and Technolog & and Att & cale & \\
\hline Media Usage and Attitude Factors & Scale & $X$ & $S$ & $r$ \\
\hline Usage subscales & & & & \\
\hline & Original Scale & 57.92 & 6.83 & \\
\hline 1-Smartphone usage & Turkish Scale & 60.51 & 6.16 & .91 \\
\hline & Original Scale & 56.55 & 5.12 & \\
\hline 2- General social-media usage & Turkish Scale & 57.08 & 6.42 & .90 \\
\hline & Original Scale & 26.85 & 7.27 & \\
\hline 3- Internet searching & Turkish Scale & 25.88 & 7.86 & .87 \\
\hline & Original Scale & 18.21 & 7.87 & \\
\hline 4- E-mailing & Turkish Scale & 18.83 & 8.16 & .88 \\
\hline & Original Scale & 22.84 & 7.30 & 89 \\
\hline 5-Media sharing & Turkish Scale & 22.55 & 7.66 & .89 \\
\hline 6- Text mescaging & Original Scale & 23.35 & 5.35 & 01 \\
\hline 0- 1ext intessagntig & Turkish Scale & 23.56 & 5.60 & (91 \\
\hline 7- Video gaming & Original Scale & 14.87 & 8.50 & 90 \\
\hline r- video gaming & Turkish Scale & 13.50 & 7.76 & .90 \\
\hline & Original Scale & 16.10 & 4.01 & 94 \\
\hline 8- Phone calling & Turkish Scale & 15.89 & 3.68 & .94 \\
\hline & Original Scale & 11.83 & 5.35 & \\
\hline 9- Television viewing & Turkish Scale & 10.91 & 5.25 & .90 \\
\hline & Original Scale & 3.81 & 2.35 & \\
\hline 10- Online friendships & Turkish Scale & 3.91 & 1.94 & .93 \\
\hline & Original Scale & 10.88 & 3.84 & \\
\hline 11- Social media friendships & Turkish Scale & 11.02 & 3.73 & .92 \\
\hline Attitudes subscales & & & & \\
\hline & Original Scale & 22.85 & 3.36 & \\
\hline 12-Positive & Turkish Scale & 22.79 & 3.15 & .92 \\
\hline 13- Anxiety and Denendence & Original Scale & 10.36 & 2.79 & 94 \\
\hline 13-Anxiety and Dependence & Turkish Scale & 9.93 & 2.69 & .94 \\
\hline 14 Nenative & Original Scale & 10.15 & 2.08 & 03 \\
\hline 14- Negauve & Turkish Scale & 10.63 & 2.27 & .93 \\
\hline & Original Scale & 12.15 & 2.38 & \\
\hline 15- Miultitasking Preferences & Turkish Scale & 12.43 & 2.73 & .91 \\
\hline
\end{tabular}


scale (positive attitudes towards technology, anxiety of being without technology/ technology dependency, negative attitudes towards technology, and multitasking preferences), which determined their opinions related to attitude, were applied using a 5-point Likert structure (definitely agree to definitely don't agree).

The findings obtained for the linguistic equivalence of the Media and Technology Usage Scale showed that the correlations between the sub-factor scores of the Turkish and original forms was .91 for smartphone usage, .90 for general socialmedia usage, .87 for Internet searching, .88 for e-mailing, .89 for media sharing, .91 for text messaging (SMS), .90 for video gaming, .94 for phone calling, .90 for television viewing, .93 for online friendships, .92 for social media friendships, .92 for positive attitudes towards technology, .94 for anxiety of being without technology/ technology dependency, .93 for negative attitudes towards technology, and .91 for multitasking preferences. The findings are shown in Table 1.

\section{Confirmatory Factor Analysis (CFA)}

As the factor pattern of the tool in the original culture had been revealed by many qualitative and quantitative operations, and as experimental evidences relevant to the structural validity of the tool had been determined during the cross-cultural scale adaptation process, confirmatory factor analysis for the scale's factors in the target culture was suggested to begin (Çokluk, Şekercioğlu, \& Büyüköztürk, 2010; Hambleton et al., 2005). Thus, confirmatory factor analysis was used for the validity study of the Media and Technology Usage and Attitudes Scale; the obtained diagram has been provided in Figure 1.

While determining the model's conformity, different goodness-of-fit indices and their statistical functions were considered (Akın \& Çetin, 2007; Gizir, 2005; Küçükturan, 2005; Tosun \& Irak, 2008). In this study's CFA, values of chi-square goodness $\left(\chi^{2}\right)$, degrees of freedom (df), goodness of fit index (GFI), adjusted goodness of fit index (AGFI), comparative fit index (CFI), normed fit index (NFI), root mean square error of approximation (RMSEA), relative fit index (RFI) and incremental fit index (IFI), which allow for the standardized root mean square residual (SRMR) value, were calculated.

Statistics related to fit in the CFA results of the scale have been provided in Table 2. As shown, $\chi^{2}=4,330.49$ and $\mathrm{df}=1,605$. The ratio of these values to each other was observed as $\chi^{2} / \mathrm{df}=2.70$. A ratio of $\chi^{2} / \mathrm{df}<3$ calculated in large samples indicates perfect fit and $\chi^{2} / \mathrm{df}<5$ indicates a middle level of fit (Kline, 2005; Sümer, 2000). Within this frame, the ratio of $\chi^{2} / \mathrm{df}$ here can be said to provide a perfect degree of fit.

When examining the NNFI and CFI fit indices, NNFI $=.95$ and CFI $=.95$ were observed. NNFI and CFI indices $>.95$ indicate perfect fit; NNFI and CFI $>.90$ indicate 


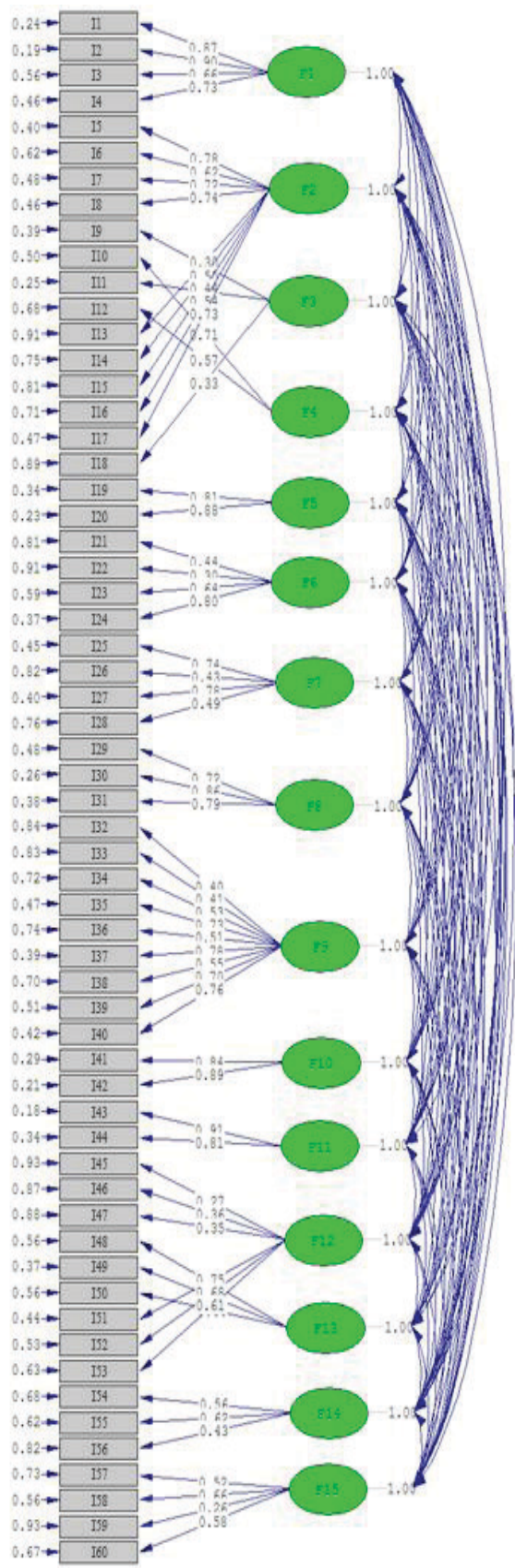

Chi-Square $=4330.49$, df $=1605$, P-value $=0.00000$, RMSEA $=0.043$

Figure 1. Diagram of confirmatory factor analysis as applied to the questions in the Media and Technology Usage and Attitudes Scale. good fit (Sümer, 2000). In this context, NNFI and CFI were observed to have good fit per the analysis. Moreover, as the IFI $=.95$ fit index value was found, which allows for an SRMR value independent of the sample, the model-data fit can be said to be good. 
In accordance with other findings presented in Table $2, \mathrm{GFI}=.93$ and AGFI $=.91$ were observed. GFI and AGFI indices $>.95$ indicate perfect fit; GFI and AGFI > .90 indicate good fit (Hooper, Coughlan, \& Mullen, 2008). Thus, the fit values obtained in the research can be said to be at a good level.

A fit index of SRMR $=.046$ was observed. Having RMR and SRMR $<.05$ indicate perfect fit, RMR and SRMR $<.08$ indicate good fit (Brown, 2006), and RMR and SRMR $<.10$ indicate weak fit (Çokluk et al., 2010). Within this frame, the obtained SRMR can be said to have perfect fit.

When examining the RMSEA in the route scheme, a fit index level of .04 was observed. While RMSEA $<.05$ indicates perfect fit and RMSEA $<.08$ indicates good fit (Jöreskog \& Sörbom, 1993), an RMSEA < 10 indicates weak fit of model-data (Tabachnick \& Fidel, 2001). In this context, the RMSEA fit index obtained from confirmatory factor analysis can be said to indicate perfect fit. Moreover, as the confidence interval of the RMSEA value covers the value of .04 within a $95 \%$ probability, the model-data fit can be said to be high.

\begin{tabular}{|c|c|c|c|c|c|c|c|c|c|c|}
\hline $\begin{array}{l}\text { Table } 2 \\
\text { Results of }\end{array}$ & Confir & itory & asto & Inalysi & (CFA & f the $M$ & ig & Technol & gy Usage & ind Attitudes Scale \\
\hline$\chi^{2}$ & df & $\mathrm{p}$ & CFI & NNFI & GFI & AGFI & IFI & SRMR & RMSEA & $\begin{array}{l}90 \% \text { Confidence Inter- } \\
\text { val for RMSEA }\end{array}$ \\
\hline 4330.49 & 1605 & $<.05$ & .95 & .95 & .93 & .91 & .95 & .046 & .043 & $.042-.045$ \\
\hline
\end{tabular}

When considering all values related to model-data fit from the CFA that were performed in relation to the model's fit, the model can be said to provide a close-toperfect fit with the data; thus, the scale has structural validity.

\section{Corrected Item-Total Correlations and Item Analyses}

First the scale was subjected to item analysis then the item characteristics were determined. Total scores and item correlations were calculated and have been provided in Table 3. Total-item correlation explains the relationship between scores obtained from test items and the total score of the test. A positive, high total-item correlation indicates that the items illustrate similar behaviors and that the test's internal consistency is high. The article-total score correlations of the adapted scale vary between .39 and .73. Büyüköztürk (2002, p.171) specified that items with an itemtotal correlation 0.30 differentiate individuals to a high degree, an item with a 0.20 item-total correlation 0.30 should be subjected to the test as it has a moderate degree of differentiation, and items with an item-total correlation .20 shouldn't be subjected to the test. In accordance with Özçelik (2010), as all item-correlation coefficients included in the scale were over .30, they are indicated to be good indicators.

Moreover, the degree of differentiation for the items of the scale was calculated. For this purpose, the raw scores obtained from each item were first ranged in descending 
order, and then the top and bottom $27 \%$ of the 247 individuals were determined. Independent group $t$-test values were calculated over the total scores in the groups. The $t$-values related to degree of differentiation and the findings related to level of significance have been provided in Table 1 . The $t$-values $(\mathrm{df}=492)$ related to differences in the item scores for the top and bottom $27 \%$ of participants were determined to be between $4.16(p<.001)$ and $24.61(p<.001)$, as per the total scores of the scale. As a result of analysis, all items were found significant $(p<.001)$. Accordingly, the items in the scale can be said to measure the same behavior.

\begin{tabular}{|c|c|c|c|c|c|}
\hline \multicolumn{6}{|c|}{$\begin{array}{l}\text { Table } 3 \\
\text { Average, standard deviation, corrected item-total co } \\
\text { the top and bottom } 27 \% \text { of the group. }\end{array}$} \\
\hline \multirow{2}{*}{ Factor Name } & \multirow{2}{*}{ Item No } & $X$ & $S$ & \multirow[b]{2}{*}{$r_{j x}$} & \multirow[b]{2}{*}{$t$} \\
\hline & & \multicolumn{2}{|c|}{ bottom $27 \%$ - top $27 \%$} & & \\
\hline \multirow{9}{*}{ 1- Smartphone usage } & I5 & $6.05-9.43$ & $2.90-1.44$ & .58 & 16.38 \\
\hline & I6 & $5.68-8.84$ & $2.52-2.00$ & .56 & 15.45 \\
\hline & I7 & $5.15-8.94$ & $2.23-1.96$ & .64 & 20.06 \\
\hline & I8 & $4.63-8.34$ & $2.58-2.36$ & .60 & 16.71 \\
\hline & $\mathrm{I} 13$ & $4.19-6.88$ & $2.72-3.18$ & .39 & 10.13 \\
\hline & $\mathrm{I} 14$ & $2.14-5.75$ & $1.65-3.54$ & .57 & 14.53 \\
\hline & $\mathrm{I} 15$ & $3.79-6.98$ & $2.51-2.98$ & .50 & 12.91 \\
\hline & $\mathrm{I} 16$ & $5.63-8.52$ & $3.01-2.61$ & .46 & 11.41 \\
\hline & $\mathrm{I} 17$ & $4.57-8.94$ & $2.67-2.04$ & .66 & 20.42 \\
\hline \multirow{9}{*}{ 2- General social-media usage } & $\mathrm{I} 32$ & $5.23-8.15$ & $2.45-2.67$ & .45 & 12.65 \\
\hline & $\mathrm{I} 33$ & $5.61-8.45$ & $2.83-2.46$ & .45 & 11.88 \\
\hline & $\mathrm{I} 34$ & $4.61-8.17$ & $2.48-2.56$ & .56 & 15.71 \\
\hline & $\mathrm{I} 35$ & $3.73-8.33$ & $1.89-2.31$ & .73 & 24.21 \\
\hline & $\mathrm{I} 36$ & $4.05-7.27$ & $2.47-2.85$ & .52 & 13.44 \\
\hline & $\mathrm{I} 37$ & $4.56-8.92$ & $2.15-1.77$ & .73 & 24.61 \\
\hline & $\mathrm{I} 38$ & $5.09-8.26$ & $2.14-2.58$ & .55 & 14.89 \\
\hline & I39 & $3.77-8.05$ & $1.83-2.55$ & .66 & 21.41 \\
\hline & $\mathrm{I} 40$ & $4.98-8.92$ & $2.33-1.77$ & .68 & 21.21 \\
\hline \multirow{4}{*}{ 3- Internet searching } & $\mathrm{I} 25$ & $4.75-8.41$ & $2.30-2.17$ & .61 & 18.16 \\
\hline & $\mathrm{I} 26$ & $5.54-7.38$ & $2.56-2.90$ & .43 & 7.46 \\
\hline & $\mathrm{I} 27$ & $4.40-8.34$ & $2.10-2.34$ & .64 & 19.71 \\
\hline & $\mathrm{I} 28$ & $5.11-7.68$ & $2.46-2.66$ & .44 & 11.13 \\
\hline \multirow{4}{*}{ 4- E-mailing } & I1 & $3.66-5.96$ & $1.93-2.94$ & .44 & 10.27 \\
\hline & $\mathrm{I} 2$ & $3.81-6.33$ & $1.84-2.88$ & .49 & 11.59 \\
\hline & I3 & $3.36-5.31$ & $1.94-3.00$ & .42 & 8.55 \\
\hline & I4 & $3.16-5.56$ & $1.66-2.96$ & .48 & 11.11 \\
\hline \multirow{4}{*}{ 5- Media sharing } & $\mathrm{I} 21$ & $5.32-8.18$ & $2.44-2.46$ & .50 & 12.99 \\
\hline & $\mathrm{I} 22$ & $5.53-7.48$ & $2.76-2.94$ & .44 & 7.58 \\
\hline & $\mathrm{I} 23$ & $2.72-6.62$ & $1.92-3.24$ & .57 & 16.26 \\
\hline & $\mathrm{I} 24$ & $3.07-7.57$ & $1.67-2.69$ & .71 & 22.29 \\
\hline \multirow{3}{*}{ 6- Text messaging } & I9 & $7.19-9.52$ & $2.29-1.41$ & .53 & 13.63 \\
\hline & I11 & $7.38-9.64$ & $2.10-1.02$ & .55 & 15.21 \\
\hline & $\mathrm{I} 18$ & $4.66-7.93$ & $2.93-2.69$ & .47 & 12.93 \\
\hline \multirow{3}{*}{ 7- Video gaming } & I29 & $3.62-8.01$ & $2.29-2.61$ & .61 & 19.87 \\
\hline & $\mathrm{I} 30$ & $2.50-6.48$ & $2.01-3.33$ & .57 & 16.06 \\
\hline & $\mathrm{I} 31$ & $2.18-6.16$ & $1.76-3.53$ & .55 & 15.86 \\
\hline \multirow{2}{*}{ 8- Phone calling } & $\mathrm{I} 10$ & $7.76-9.60$ & $1.90-1.13$ & .52 & 13.18 \\
\hline & $\mathrm{I} 12$ & $5.53-8.65$ & $3.14-2.44$ & .48 & 12.35 \\
\hline
\end{tabular}


Table 3

Average, standard deviation, corrected item-total correlations and $\mathrm{t}$-values related to scale difference between the top and bottom $27 \%$ of the group.

\begin{tabular}{|c|c|c|c|c|c|}
\hline \multirow{2}{*}{ Factor Name } & \multirow{2}{*}{ Item No } & $X$ & $S$ & \multirow{2}{*}{$r_{j x}$} & \multirow{2}{*}{$t$} \\
\hline & & \multicolumn{2}{|c|}{ bottom $27 \%$ - top $27 \%$} & & \\
\hline \multirow{2}{*}{ 9- Television viewing } & I19 & $4.53-7.43$ & $2.60-2.79$ & .47 & 11.93 \\
\hline & $\mathrm{I} 20$ & $3.81-6.86$ & $2.47-3.05$ & .48 & 12.24 \\
\hline \multirow{2}{*}{ 10- Online friendships } & I43 & $1.99-2.41$ & $.96-1.29$ & .53 & 4.16 \\
\hline & I44 & $1.70-2.23$ & $.74-1.37$ & .56 & 5.35 \\
\hline \multirow{2}{*}{ 11- Social media friendships } & I41 & $4.69-6.16$ & $1.84-1.89$ & .46 & 8.78 \\
\hline & $\mathrm{I} 42$ & $4.43-5.66$ & $1.58-1.69$ & .46 & 8.39 \\
\hline \multirow{6}{*}{ 12- Positive Attitudes } & I45 & $3.98-4.52$ & $1.00-1.16$ & .61 & 5.36 \\
\hline & I46 & $3.96-4.46$ & $.95-1.05$ & .59 & 4.46 \\
\hline & I47 & $3.98-4.58$ & $.90-.97$ & .48 & 4.41 \\
\hline & I51 & $3.47-3.98$ & $.95-1.09$ & .60 & 5.55 \\
\hline & I52 & $2.95-3.74$ & $1.02-1.16$ & .41 & 8.02 \\
\hline & I53 & $3.10-3.63$ & $.99-1.14$ & .58 & 5.56 \\
\hline \multirow{3}{*}{ 13- Anxiety and Dependence } & $\mathrm{I} 48$ & $3.30-4.00$ & $1.02-1.17$ & .44 & 7.14 \\
\hline & I49 & $2.77-3.72$ & $1.07-1.18$ & .41 & 9.34 \\
\hline & $\mathrm{I} 50$ & $2.53-3.68$ & $1.06-1.10$ & .46 & 11.79 \\
\hline \multirow{3}{*}{ 14- Negative Attitudes } & I54 & $3.51-4.08$ & $1.06-1.07$ & .55 & 4.81 \\
\hline & I55 & $3.17-3.87$ & $1.03-1.15$ & .61 & 6.62 \\
\hline & I56 & $3.72-4.56$ & $1.06-1.11$ & .73 & 6.71 \\
\hline \multirow{4}{*}{ 15- Multitasking Preferences } & I57 & $3.03-3.34$ & $1.05-1.20$ & .68 & 15.11 \\
\hline & I58 & $2.80-3.27$ & $1.07-1.25$ & .71 & 9.49 \\
\hline & I59 & $2.69-3.48$ & $1.01-1.17$ & .68 & 8.89 \\
\hline & $\mathrm{I} 60$ & $2.77-3.85$ & $1.06-1.34$ & .59 & 7.98 \\
\hline
\end{tabular}

${ }^{I} n=913$ $* p<.001$

The correlation analysis between each factor of the scale has been provided in Table 4 . The obtained findings reveal a positive relationship at the level of $p<.001$ the between factors.

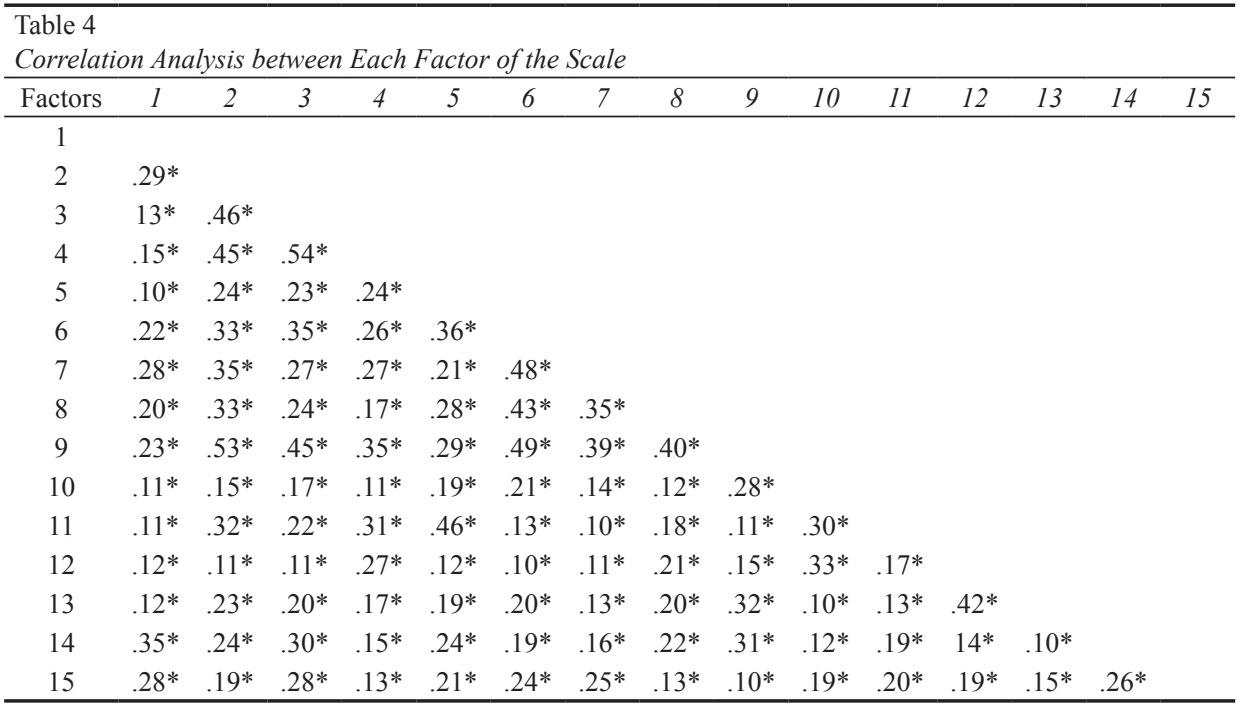
$* p<.001$. 


\section{Reliability}

With the purpose of examining the correlation between each item's score and the total test score, when responses provided to the items were three or more, Cronbach's alpha was calculated. The reliability coefficient of $\alpha .70$ is considered sufficient for reliability of test scores (Büyüköztürk, 2002, p. 170). As observed in Table 3, Cronbach's alpha coefficients for the fifteen factors that are included in the Media and Technology Usage and Attitudes Scale vary between .71 and .89. Moreover, the Spearman Brown split-half test correlations of the factors in this scale were examined, and the findings have been provided in Table 5.

\begin{tabular}{lccccc}
\hline $\begin{array}{l}\text { Table 5 } \\
\text { Cronbach's Alpha and Spearman Brown Split-half Test Reliability }\end{array}$ & & & \\
\hline Factors & Cronbach's $\alpha$ & $\begin{array}{c}\text { Split-half } \\
\text { correlation }\end{array}$ & Factors & Cronbach's $\alpha$ & $\begin{array}{c}\text { Split-half } \\
\text { correlation }\end{array}$ \\
\hline F1 & .89 & .86 & F9 & .83 & .78 \\
F2 & .82 & .81 & F10 & .85 & .85 \\
F3 & .78 & .71 & F11 & .87 & .83 \\
F4 & .74 & .75 & F12 & .76 & .73 \\
F5 & .85 & .85 & F13 & .74 & .71 \\
F6 & .76 & .70 & F14 & .82 & .77 \\
F7 & .71 & .76 & F15 & .76 & .71 \\
F8 & .84 & .82 & & & \\
\hline
\end{tabular}

As observed in Table 5, the split-half test correlation values for the sub-factors of the scale were between .71 and .86. When Cronbach's alpha coefficients and Spearman Brown split-half test correlations are examined, the values are observed to be sufficient for the reliability of Media and Technology Usage and Attitudes Scale.

\section{Discussion, Conclusion and Suggestions}

In the context of this study, the Media and Technology Usage and Attitudes Scale, which had been developed by Rosen et al. (2013), was adapted to Turkish. Within the scope of the study, validity of language and validity of structure and differentiating features of the items were examined, and the correlation coefficients among the subfactors of the scale were determined for testing the validity and reliability of the Turkish form of this scale. Moreover, internal reliability coefficients for the factors included in the scale were calculated with Cronbach's alpha coefficient values. Cronbach's alpha coefficients for the sub-factors of the scale were shown to vary between .71 and .89; the split-half test correlations related to the sub-factors of the scale vary between .71 and .86 . Considering the limits of the fit index performed in confirmatory factor analysis, the model has been observed to show good fit and the Turkish version of the original factor structure of the scale matches; the number of items that comprise the scale did not change. According to the obtained findings, the Media and Technology Usage and Attitudes Scale has been proven to be a valid and 
reliable measurement tool. In conclusion, the structure with 15 factors and 60 items (the original form of the scale developed in order to determine attitudes towards media and technology usage through 11 factors and determine media and technology usage through 4 factors) and the structure in the Turkish form have been determined to conform with each other.

While some of the 31 items included in the first eight factors of the adapted scale (such as Television viewing) measure the usage frequency of old technologies, they also include different sub-factors that had been prepared in order to separately determine the usage frequencies of new technologies (such as smartphone usage, e-mailing, Internet searching). While two factors (nine items) included in the scale intend to determine the usage frequency of Facebook social network (We Are Social, 2014), which has the most number of users in the world and is frequently used by the majority of individuals in Turkish society who have an Internet connection, another sub-factor (four items) intends to determine the number of friends one has on Facebook. In this context, the names of different social networks may also be used instead of Facebook within these three sub-factors. The final four factors (16 items) of the scale consist of items where attitude phrases were asked to reveal anxiety towards technology and dependency on technology, as well as positive or negative attitudes towards technology, without making specific distinctions of technology. One of these four sub-factors is intended for determining individuals' multitasking preferences while completing a task.

This research has some limitations. The study's analyses being performed over a single data group (teacher candidates) is one significant limitation of the study. Another one is that teacher candidates' assessments of their own personal selfperceptions formed the data that was obtained for analyses. In this context, results obtained from adaptation operations performed on larger samples where individuals of different age groups and demographic features are included are considered able to contribute to the validity and reliability of the scale by comparing those results with the ones obtained in this study. Thus, through future research such as status studies and formation of theory in a qualitative context, the effects of the general findings on the sample may be assessed on more specific samples. Moreover, results obtained by the adapted scale in qualitative and quantitative researches that are made with the participation of individuals from different demographics is considered able to contribute to supporting evidence related to the validity and reliability of this scale. 


\section{References}

Akın, A., \& Çetin, B. (2007). The Depression Anxiety and Stress Scale (DASS): The study of validity and reliability. Educational Sciences: Theory \& Practice, 7(1), 241-268.

Aksayan, S., \& Gözüm, S. (2002). Kültürlerarası ölçek uyarlaması için rehber I: Ölçek uyarlama aşaması ve dil uyarlamaları [A guide for transcultural adaptation of the scale]. Hemşirelik Araştırma Dergisi, 4(1), 9-14.

Alloway, T., \& Alloway, R. (2011). Attentional control and engagement with digital technology. Nature Proceedings, Nature Publishing Group. Retrieved from http://precedings.nature. com $/$ documents $/ 5603 /$ version $/ 1 / \mathrm{html}$

Anderson, C. A., Gentile, D. A., \& Buckley, K. (2007). Violent video game effects on children and adolescents: Theory, research, and public policy. New York, NY: Oxford University Press.

Aslan, A., \& Zhu, C. (2015). Pre-service teachers' perceptions of ICT integration in teacher education in Turkey. TOJET: Turkish Online Journal of Educational Technology, 14(3), 97-110.

Aydın, F., Karaa, F. N. (2013). Öğretmen adaylarının teknolojiye yönelik tutumları: Ölçek geliştirme çalışması [Pre-service teachers' attitudes toward technology: Scale development study]. Türk Fen Eğitimi Dergisi, 10(4), 103-118.

Balduini, M., Celino, I., Dell'Aglio, D., Della, E. V., Huang, Y., Lee, T., ...Tresp, V. (2012). BOTTARI: An augmented reality mobile application to deliver personalized and locationbased recommendations by continuous analysis of social media streams. Web Semantics: Science, Services and Agents on the World Wide Web, 16, 33-41.

Baran, B. (2013). Çoklu görev(ler)'in öğretim elemanlarının akademik işlerine etkisi [The effect of multitasking to faculty members' academic works]. Educational Sciences: Theory \& Practice, 13, 2337-2353. Retrieved from http://dx.doi.org/10.12738/estp.2013.4.1718

Baron, N. S. (2008). Adjusting the volume: Technology and multitasking in discourse control. In J. E. Katz (Ed.), Handbook of Mobile Communication Studies (pp. 177-194). Cambridge, MA: MIT Press.

Baş, T. (2006). Anket [Survey]. Ankara, Turkey: Seçkin Yayıncılık.

Benbunan-Fich, R., Adler, R. F., \& Mavlanova, T. (2011). Measuring multitasking behavior with activity-based metrics. ACM Transactions on Computer-Human Interaction, 18(2), 1-22.

Berigel, M., Kokoç, M., \& Karal, H. (2012). Exploring pre-service teachers' level of social networking sites addictive tendencies. Eğitim Araştırmaları-Eurasian Journal of Educational Research, 49(A), 215-228.

Brasel, S. A., \& Gips, J. (2011). Media multitasking behavior: Concurrent television and computer usage. Cyberpsychology, Behavior, and Social Networking, 14(9), 527-534.

Burak, L. (2012). Multitasking in the university classroom. International Journal for the Scholarship of Teaching and Learning, 6(2), 1-12. Retrieved from http://vc.bridgew.edu/mahpls_fac/74/

Büyüköztürk, Ş. (2002). Sosyal bilimler için veri analizi el kitabı [Data analysis handbook for social sciences] (11st ed.). Ankara, Turkey: PegemA Yayıncılık.

Büyüköztürk, Ş., Çakmak, E. K., Akgün, Ö. E., Karadeniz, Ş., \& Demirel, F. (2014). Bilimsel araştırma yöntemleri [Scientific research methods] (16th ed.). Ankara, Turkey: Pegem Akademi.

Cades, D. M., Werner, N. E., Boehm-Davis, D. A., \& Arshad, Z. (2010). Interruptions are disruptive in the real world: Evidence from an office setting. In Proceedings of the 54th annual human factors and ergonomics society conference. San Francisco, CA: Human Factors and Ergonomics Society.

Cakir, R. (2015). Pre-service and in-service teachers' perceptions about using Web 2.0 in education. Participatory Educational Research, 2(2), 70-83. Retrieved from http://dx.doi. org/10.17275/per.15.10.2.2 
Carrier, L. M., Cheever, N. A., Rosen, L. D., Benitez, S., \& Chang, J. (2009). Multitasking across generations: Multitasking choices and difficulty ratings in three generations of Americans. Computers in Human Behavior, 25, 483-489.

Carrier, L. M., Rosen, L. D., Cheever, N. A., \& Lim, A. F. (2015). Causes, effects, and practicalities of everyday multitasking. Developmental Review, 35, 64-78. Retrieved from http://dx.doi.org/10.1016/j.dr.2014.12.005

Clayton, R. B., Osborne, R. E., Miller, B. K., \& Oberle, C. D. (2013). Loneliness, anxiousness, and substance use as predictors of Facebook use. Computers in Human Behavior, 29(3), 687-693.

Council of Higher Education (CoHE, Turkey). (2015). Öğrenci sayllart istatistikleri [The statistics of students]. Retrieved from https://istatistik.yok.gov.tr/ yuksekogretimIstatistikleri/2015/2015_T17.pdf

Çam, E., \& İşbulan, O. (2012). Addiction for teacher candidates: Social networks. TOJET: The Turkish Online Journal of Educational Technology, 11(3), 14-19.

Çepni, O., Palaz, T., \& Ablak, S. (2015). Sosyal bilgiler öğretmen adaylarının medya ve televizyon okuryazarlık düzeylerinin çeşitli değişkenlere göre incelenmesi [Examining prospective social sciences teachers' level of media and television literacy according to different variables]. Turkish Studies, 10(11), 431-446. Retrieved from http://dx.doi.org/10.7827/TurkishStudies.8464

Çetin, B. (2015). Determination of media and television literacy levels of classroom teacher candidates. Journal of Theory and Practice in Education, 11(1), 171-190.

Çoklar, A. N. (2014). Sınıf öğretmenliği öğretmen adaylarının teknolojik pedagojik içerik bilgisi yeterliklerinin cinsiyet ve BİT kullanım aşamaları bağlamında incelenmesi [Primary school preservice teachers' technological pedagogical content knowledge competency in terms of gender and ICT use phase]. Eğitim ve Bilim, 39(175), 103-122. Retrieved from http://dx.doi.org/10.15390/EB.2014.3464

Çokluk, Ö., Şekercioğlu, G., \& Büyüköztürk, Ş. (2010). Sosyal bilimler için çok değişkenli istatistik SPSS ve LISREL uygulamalart [Multivariate statistics for the social sciences SPSS and LISREL applications]. Ankara, Turkey: Pegem Akademi Yayınevi.

Çuhadar, C., Bülbül, T., \& Ilgaz, G. (2013). Öğretmen adaylarının bireysel yenilikçilik özellikleri ile teknopedagojik eğitim yeterlikleri arasındaki ilişkinin incelenmesi [Exploring of the relationship between individual innovativeness and techno-pedagogical education competencies of pre-service teachers]. Ilköğretim Online, 12(3), 797-807.

Delbridge, K. A. (2000). Individual differences in multi-tasking ability: Exploring a nomological network (unpublished doctoral dissertation). Michigan State University, Department of Psychology.

Demirli, C. (2013). ICT usage of pre-service teachers: Cultural comparison for Turkey and Bosnia and Herzegovina. Educational Sciences: Theory \& Practice, 13, 1095-1105.

Deniz, Z. (2007). Psikolojik ölçme aracı uyarlama [The adaptation of psychological scales]. Ankara Üniversitesi Ë̈itim Bilimleri Fakültesi Dergisi, 40(1), 1-16.

D'heer, E., Courtois, C., \& Paulussen, S. (2012). The dynamics of multi-screen media consumption in the living room context. Proceedings of the 10th European conference on Interactive TV and video. Berlin, Germany.

Dindar, M., \& Akbulut, Y. (2014). Why do pre-service teachers quit Facebook? An investigation on 'quitters forever' and 'quitters for a while'. Computers in Human Behavior, 39, 170176. Retrieved from http://dx.doi.org/10.1016/j.chb.2014.07.007

Dindar, M., \& Akbulut, Y. (2016). Effects of multitasking on retention and topic interest. Learning and Instruction, 41, 94-105. Retrieved from http://dx.doi.org/10.1016/j. learninstruc.2015.10.005 
Ellison, N. B., Steinfield, C., \& Lampe, C. (2011). Connection strategies: Social capital implications of Facebook-enabled communication practices. New Media \& Society, 13(6), 873-892.

Foehr, U. G. (2006). Key Findings: Media multitasking among American youth: Prevalence, predictors and pairings. A Kaiser Family Foundation study. Retrieved from http://kff.org/ other/media-multitasking-among-american-youth-prevalence-predictors-2/

Gizir, S. (2005). Assessment of factors negatively effecting the communication process in Turkish state universities (Doctoral dissertation). Thesis no. 161941 retrieved from https:// tez.yok.gov.tr/UlusalTezMerkezi/

Golbeck, J. (2013). Analyzing the social web. Burlington, MA: Morgan Kaufmann.

Google. (2013). Our mobile planet: Turkey. Understanding the mobile consumer. Retrieved from http://services.google.com/fh/files/misc/omp-2013-tr-local.pdf

Green, C. S., \& Bavelier, D. (2003). Action video game modifies visual selective attention. Nature, 423, 534-537.

Hambleton, R. K., Merenda, F. P., \& Spielberger, C. D. (2005). Adapting educational and psychological tests for cross-cultural assessment. Mahwah, NJ: Lawrence Erlbaum Associates.

Hambleton, R. K., \& Patsula, L. (1999). Increasing the validity of adapted tests: Myths to be avoided and guidelines for improving test adaptation practices. Journal of Applied Testing Technology, 1(1), 1-30.

Hambrick, D. Z., Oswald, F. L., Darowski, E. S., Rench, T. A., \& Brou, R. (2010). Predictors of multitasking performance in a synthetic work paradigm. Applied Cognitive Psychology, 24(8), 1149-1167. Retrieved from http://dx.doi.org/10.1002/acp.1624

Hampton, K. L., Goulet, L. S., Rainie, L., \& Purcell, K. (2011). Social networking sites and our lives. Washington, DC: Pew Internet and American Life Project. Retrieved from http:// www.pewinternet.org/2011/06/16/social-networking-sites-and-our-lives

Han, I., Eom, M., \& Shin, W. S. (2013). Multimedia case-based learning to enhance pre-service teachers' knowledge integration for teaching with Technologies. Teaching and Teacher Education, 34, 122-129. Retrieved from http://dx.doi.org/10.1016/j.tate.2013.03.006

Hao, Y. (2016). The development of pre-service teachers' knowledge: A contemplative approach. Computers in Human Behavior, 60, 155-164. Retrieved from http://dx.doi. org/10.1016/j.chb.2016.02.054

Holmes, M. E., Papper, R. A., Popovich, M. N., \& Bloxham, M. (2005). Middletown media studies II: Concurrentmedia exposure. Muncie, IN: Ball State Univ. Center for Media Design. Retrieved from http://cms.bsu.edu/academics/centersandinstitutes/cmd/insightandresearch/ capabilities/projectgallery/middletownmediastudies/middletownmediastudiesii

Hooper, D., Coughlan, J., \& Mullen, M. (2008). Structural equation modeling: Guidelines for determining model fit. The Electronic Journal of Business Research Methods, 6(1), 53-60.

Hughes, J. E., Ko, Y., Lim, M., \& Liu, S. (2015). Preservice teachers' social networking use, concerns, and educational possibilities: Trends from 2008-2012. Journal of Technology and Teacher Education, 23(2), 185-212.

Hwang, Y., Kim, H., \& Jeong, S. H. (2014). Why do media users multitask? Motives for general, medium-specific, and content-specific types of multitasking. Computers in Human Behavior, 36, 542-548.

International Data Corperation (IDC). (2013). Always connected: How smartphones and social media keep us engaged. IDC Research. Retrieved from http://tr.scribd.com/doc/133393152/ IDC-Facebook-Always-Connected

International Society for Technology in Education (ISTE). (2008). National educational standards for teachers. Retrieved from http://www.iste.org/docs/pdfs/nets-tstandards. pdf? sfvrsn=2 
İşçitürk, B., \& Kabakçı Yurdakul, I. (2014). Examining pre-service teachers〉 use and acceptance of information and communication technologies in terms of certain variables. Journal of Theory \& Practice in Education, 10(3), 684-702.

Jenkins-Guarnieri, M. A., Wright, S. L., \& Johnson, B. (2013a). Development and validation of a social media use integration scale. Psychology of Popular Media Culture, 2(1), 38-50. Retrieved from http://dx.doi.org/10.1037/a0030277

Jenkins-Guarnieri, M. A., Wright, S. L., \& Johnson, B. (2013b). The interrelationships among attachment style, personality traits, interpersonal competency, and Facebook use. Psychology of Popular Media Culture, 2(2), 117-131. Retrieved from http://dx.doi.org/10.1037/a0030946

Jeong, S., \& Fishbein, M. (2007). Predictors of multitasking with media: Media factors and audience factors. Media Psychology, 10, 364-384.

Jiménez, J. E., \& O'Shanahan, I. (2016). Effects of web-based training on Spanish pre-service and in-service teacher knowledge and implicit beliefs on learning to read. Teaching and Teacher Education, 55, 175-187. Retrieved from http://dx.doi.org/10.1016/j.tate.2016.01.006

Jöreskog, K. G., \& Sörbom, D. (1993). LISREL 8: Structural equation modeling with SIMPLIS command language. Lincolnwood: Scientific Software International, Inc.

Judd, T. (2014). Making sense of multitasking: The role of Facebook. Computers \& Education, 70(2014), 194-202.

Junco, R. (2012a). Too much face and not enough books: The relationship between multiple indices of Facebook use and academic performance. Computers in Human Behavior, 28(1), 187-198.

Junco, R. (2012b). The relationship between frequency of Facebook use, participation in Facebook activities, and student engagement. Computers \& Education, 58(1), 162-171.

Junco, R. (2013). Comparing actual and self-reported measures of Facebook use. Computers in Human Behavior, 29(3), 626-631.

Junco, R. (2014). iSpy: Seeing what students really do online. Learning, Media and Technology, $39(1), 75-89$.

Junco, R., \& Cotten, S. R. (2011). Perceived academic effects of instant messaging use. Computers \& Education, 56(2), 370-378.

Junco, R., \& Cotten, S. R. (2012). No a 4u: The relationship between multitasking and academic performance. Computers \& Education, 59(2), 505-514.

Judd, T., \& Kennedy, G. (2010). A five-year study of on-campus internet use by undergraduate biomedical students. Computers and Education, 55(4), 1564-1571.

Kabakçı Yurdakul, I. (2011). Öğretmen adaylarının teknopedagojik eğitim yeterliklerinin bilgi ve iletişim teknolojilerinin kullanımları açısından incelenmesi [Examining technopedagogical knowledge competencies of preservice teachers based on ICT usage]. Hacettepe Universitesi Ë̆itim Fakültesi Dergisi, 40, 397-408.

Kahveci, N. G. (2015). Pre-service teachers' conceptions on use of social media in social studies education. International Journal of Progressive Education, 11(1), 82-100.

Kaleli Yılmaz, G. (2015). Türkiye'deki teknolojik pedagojik alan bilgisi çalışmalarının analizi: Bir meta-sentez çalışması [Analysis of technological pedagogical content knowledge studies in Turkey: A meta-synthesis study]. Eğitim ve Bilim, 40(178), 130-122.

Kalpidou, M., Costin, D., \& Morris, J. (2011). The relationship between Facebook and the well-being of undergraduate college students. Cyberpsychology, Behavior and Social Networking, 14(4), 183-189.

Kamibeppu, K., \& Sugiura, H. (2005). Impact of the moblie phone on junior high-school students' friendships in the Tokyo metropolitan area. CyberPsychology \& Behavior, 8(2), 121-130. 
Karaman, M. K. (2010). Öğretmen adaylarının TV ve internet teknolojilerini kullanma amaç ve beklentilerinin medya okuryazarlığı bağlamında değerlendirilmesi [Evaluating preservice teachers' usage purposes and expectations of TV and Internet technologies in media literacy context]. Uşak Üniversitesi Sosyal Bilimler Dergisi, 3(2), 51-62.

Kaya, S., \& Dağ, F. (2013). Sınıf öğretmenlerine yönelik teknolojik pedagojik içerik bilgisi ölçeğinin Türkçe'ye uyarlanması [Turkish adaptation of technological pedagogical content knowledge survey for elementary teachers]. Educational Sciences: Theory \& Practice, 13(1), 291-306.

Kessler, S. (2011). 38\% of college students can't go 10 minutes without tech [STATS]. Mashable Tech. Retrieved from http://mashable.com/2011/05/31/college-tech-device-stats/

Kline, R. B. (2005). Principles and practice of structural equation modeling. New York, NY: Guilford Publications, Inc.

Kraushaar, J. M., \& Novak, D. (2010). Examining the effects of student multitasking with laptops during the lecture. Journal of Information Systems Education, 21(2), 241-251.

Kraut, R., Patterson, M., Lundmark, V., Kiesler, S., Mukopadhyay, T., \& Scherlis, W. (1998). Internet paradox. A social technology that reduces social involvement and psychological well-being? American Psychologist, 53(9), 1017-1031.

Kuzu, E. B., \& Akbulut, Y. (2013). Use of online social networking sites among pre-service information technology teachers. World Journal on Educational Technology, 5(3), 358-370.

Küçükturan, G. (2005). Anne baba tutum ölçeği [Parents attitude scale]. Eğitim Araştırmalarl Dergisi, 19, 238-250.

Lampe, C., Wohn, D. Y., Vitak, J., Ellison, N. B., \& Wash, R. (2011). Student use of Facebook for organizing collaborative classroom activities. Computer-Supported Collaborative Learning, 6, 329-347.

Lawson, D. R. (2013). The effects of text messaging on memory recall in college (Doctoral dissertation). Retrieved from https://libres.uncg.edu/ir/wcu/f/Lawson2013.pdf

Lee, Y., \& Lee, J. (2014). Enhancing pre-service teachers' self-efficacy beliefs for technology integration through lesson planning practice. Computers \& Education, 73, 121-128. http:// dx.doi.org/10.1016/j.compedu.2014.01.001

Lenhart, A., Purcell, L., Smith, A., \& Zickuhr, K. (2010). Social media and young adults. Pew Internet and American Life Project. Retrieved from http://www.pewinternet.org/ Reports/2010/Social-Media-and-Young-Adults.aspx

MacCallum, R. C., Browne, M. W., \& Sugawara, H. M. (1996). Power analysis and determination of sample size for covariance structure models. Psychological Methods, 1, 130-149.

Mazman, S. G., \& Usluel, Y. K. (2010). Modeling educational usage of Facebook. Computers \& Education, 55(2), 444-453. Retrieved from http://dx.doi.org/10.1016/j. compedu.2010.02.008

McCord, B., Rodebaugh, T. L., \& Levinson, C. A. (2014). Facebook: Social uses and anxiety. Computers in Human Behavior, 34, 23-27. Retrieved from http://dx.doi. org/10.1016/j.chb.2014.01.020

Media Metrix. (1999). Simultaneous use of PC and television growing rapidly. New York, NY: Author. Retrieved from http://www.mediametrix.com/usa/press/releases/19990712.jsp

Ministry of National Education in Turkey (MoNE). (2013). Milli Ĕgitim Bakanliğl ögretmen yeterlikleri [The Ministry of National Education teacher qualifications]. Retrieved from http://otmg.meb.gov.tr/YetGenel.html

Monsell, S. (2003). Task switching. TRENDS in Cognitive Sciences, 7(3), 134-140. 
Moore, K., \& McElroy, J. C. (2012). The influence of personality on Facebook usage, wall postings, and regret. Computers In Human Behavior, 28(1), 267-274. Retrieved from http://dx.doi.org/10.1016/j.chb.2011.09.009

Moreno, M. A., Jelenchick, L., Koff, R., \& Eikoff, J. (2012a). Depression and Internet use among older adolescents: An experience sampling approach. Psychology, 3, 743-748.

Moreno, M. A., Jelenchick, L., Koff, R., Eikoff, J., Diermyer, C., \& Christakis, D. A. (2012b). Internet use and multitasking among older adolescents: An experience sampling approach. Computers in Human Behavior, 28, 1097-1102.

Mouza, C., \& Karchmer-Klein, R. (2013). Promoting and assessing pre-service teachers' technological pedagogical content knowledge (TPAC) in the context of case development. J. Educational Computing Research, 48(2), 127-152.

Nielsen. (2013). Action figures: How second screens are transforming TV viewing. Retrieved from http://www.nielsen.com/us/en/newswire/2013/action-figures--how-second-screensare-transforming-tv-viewing.html

Nielsen Media Research. (1999). TV viewing in Internet households. New York. NY: Author. Retrieved from http://www.nielsenmedia.com

Nielsen, W., Moll, R., Farrell, T., McDaid, N., \& Hoban, G. (2013). Social media use among pre-service primary teachers. International Journal of Instructional Technology and Distance Learning, 10(8), 3-13.

Ophir, E., Nass, C., \& Wagner, A. (2009). Cognitive control in media multitaskers. Proceedings of the National Academy of Sciences, 106(37), 15,583-15,587.

Öner, N. (1987). Kültürlerarası ölçek uyarlamasında bir yöntembilim modeli [Cross-cultural adaptation of the scale model of a methodology]. Psikoloji Dergisi, 6(21), 80-83.

Özçelik, D. A. (2010). Test hazırlama kılavuzu [Test preparation guide]. Ankara, Turkey: PEGEM A Yayıncılık.

Özgür, H. (2013). Öğretmen adaylarının sosyal ağ bağımlılığı, etkileşim kaygısı ve yalnızlık düzeyi arasındaki ilişkinin incelenmesi [Analyzing the relationship between social networking addiction, interaction anxiousness and levels of loneliness of pre-service teachers]. Uluslararası Insan Bilimleri Dergisi, 10(2), 667-690.

Papper, R. A., Holmes, M. E., \& Popovich, M. N. (2004). Middletown media studies: Media multitasking and how much people really use the media. The International Digital Media and Arts Association Journal, 1, 9-50.

Pashler, H., Kang, S. H., \& Ip, R. Y. (2013). Does multitasking 1mpair studying? Depends on timing. Applied Cognitive Psychology, 27(5), 593-599.

Piotrowski, C. (2015). Emerging research on social media use in education: A study of dissertations. Research in Higher Education Journal, 27, 1-12.

Poposki, E. M., \& Oswald, F. L. (2010). The multitasking preference inventory: Toward an improved measure of individual differences in polychronicity. Human Performance, 23, 247-264.

Ravizza, S. M., Hambrick, D. Z., \& Fenn, K. M. (2014). Non-academic internet use in the classroom is negatively related to classroom learning regardless of intellectual ability. Computers \& Education, 78, 109-114.

Rideout, V. J., Foehr, U. G., \& Roberts, D. F. (2010). Generation M2: Media in the Lives of 8-18 year olds. Menlo Park, CA: Kaiser Family Foundation.

Rideout, V. J., Foehr, U. G., Roberts, D. F., \& Brodie, M. (1999). Kids and media at the new millennium: A comprehensive national analysis of children's media use. Palo Alto, CA: Kaiser Family Foundation. 
Rosen, L. D., Carrier, L. M., \& Cheever, N. A. (2013). Facebook and texting made me do it: Mediainduced task-switching while studying. Computers in Human Behavior, 29(3), 948-958.

Rosen, L. D., Whaling, K., Carrier, L. M., Cheever, N. A., \& Rokkum, J. (2013a). The media and technology usage and attitudes scale: An empirical investigation. Computers in Human Behavior, 29(6), 2501-2511. Retrieved from http://dx.doi.org/10.1016/j.chb.2013.06.006

Rosen, L. D., Whaling, K., Rab, S., Carrier, L. M., \& Cheever, N. A. (2013b). Is Facebook creating "iDisorders"? The link between clinical symptoms of psychiatric disorders and technology use, attitudes and anxisety. Computers in Human Behavior, 29, 1243-1254.

Ryan, T., \& Xenos, S. (2011). Who uses Facebook? An investigation into the relationship between the Big Five, shyness, narcissism, loneliness, and Facebook usage. Computers in Human Behavior, 27(5), 1658-1664. Retrieved from http://dx.doi.org/10.1016/j.chb.2011.02.004

Sana, F., Weston, T., \& Cepeda, N. J. (2013). Laptop multitasking hinders classroom learning for both users and nearby peers. Computers \& Education, 62, 24-31.

Sarsar, F, \& Engin, G. (2015). Sınıf öğretmeni adaylarının medya okur-yazarlık düzeylerinin incelenmesi [Investigation of the media literacy level of primary school teacher candidates]. Ege Eğitim Dergisi, 1(16), 165-176.

Sendurur, P., Sendurur, E., \& Yilmaz, R. (2015). Examination of the social network sites usage patterns of pre-service teachers. Computers in Human Behavior, 51(A), 188-194. http:// dx.doi.org/10.1016/j.chb.2015.04.052

Subrahmanyam, K., Greenfield, P., Kraut, R., \& Gross, E. (2001). The impact of computer use on children's and adolescents' development. Applied Developmental Psychology, 22, 7-30.

Salvucci, D. D., \& Taatgen, N. A. (2010). The multitasking mind. Oxford, UK: Oxford University Press.

Savaşır, I. (1994). Ölçek uyarlamasındaki bazı sorunlar ve çözüm yolları [Problems and some solutions in scale adaptation]. Türk Psikoloji Dergisi, 33(9), 27-32.

Sümer, N. (2000). Yapısal eşitlik modelleri: Temel kavramlar ve örnek uygulamalar [Structural equation modeling: Basic concepts and sample applications]. Türk Psikoloji Yazllarl, 3(6), 49-74.

Tabachnick, B. G., \& Fidell, L. S. (2001). Using multivariate statistics (4th ed.).Boston, MA: Allyn \& Bacon.

Teo, T. (2015). Comparing pre-service and in-service teachers' acceptance of technology: Assessment of measurement invariance and latent mean differences. Computers \& Education, 83, 22-31. Retrieved from http://dx.doi.org/10.1016/j.compedu.2014.11.015

Teo, T., \& Noyes, J. (2014). Explaining the intention to use technology among pre-service teachers: A multi-group analysis of the Unified Theory of Acceptance and Use of Technology (UTAUT). Interactive Learning Environments, 22(1), 51-66.

Thompson, P. (2013). The digital natives as learners: Technology use patterns and approaches to learning. Computers and Education, 65, 12-33.

Tindell, D. R., \& Bohlander, R. W. (2012). The use and abuse of cell phones and text messaging in the classroom: A survey of college students. College Teaching, 60(1), 1-9. Retrieved from http://dx.doi.org/10.1080/87567555.2011.604802

Tokmak Sancar, H., Yelken Yanpar, T., \& Konokman Yavuz, G. (2013). Pre-service teachers' perceptions on development of their IMD competencies through TPACK-based activities. Educational Technology \& Society, 16(2), 243-256.

Tondeur, J., Van Braak, J., Siddiq, F., \& Scherer, R. (2016). Time for a new approach to prepare future teachers for educational technology use: Its meaning and measurement. Computers \& Education, 94, 134-150. Retrieved from http://dx.doi.org/10.1016/j.compedu.2015.11.009 
Tosun, A., \& Irak, M. (2008). Adaptation, validity, and reliability of the Metacognition Questionnaire-30 for the Turkish population, and its relationship to anxiety and obsessivecompulsive symptoms. Turkish Journal of Psychiatry, 19(1), 67-80.

Trepte, S., \& Reinecke, L. (2013). The reciprocal effects of social network site use and the disposition for self-disclosure: A longitudinal study. Computers in Human Behavior, 29, $1102-1112$.

Ursavaş, Ö. F. (2015). An examination of gender effect on preservice teachers' behavioural intentions to use ICT. Ë̌itimde Kuram ve Uygulama, 11(1), 68-88.

Ursavaş, Ö. F., Şahin, S, \& McIlroy, D. (2014). Türkiye'deki öğretmen adaylarının BİT kullanımına yönelik davranışsal niyetlerinin belirlenmesinde branşlarının rolü [The role of discipline in determining Turkish pre-service teachers' behavioral intentions to use ICT]. Eğitim ve Bilim, 39(175), 136-153.

Valtonen, T., Kukkonen, J., Kontkanen, S., Sormunen, K., Dillon, P., \& Sointu, E. (2015). The impact of authentic learning experiences with ICT on pre-service teachers' intentions to use ICT for teaching and learning. Computers \& Education, 81, 49-58. http://dx.doi. org/10.1016/j.compedu.2014.09.008

Vitak, J., Zube, P., Smock, A., Carr, C. T., Ellison, N., \& Lampe, C. (2011). It's complicated: Facebook users' political participation in the 2008 election. Cyberpsychology, Behavior and Social Networking, 14(3), 107-114.

Wang, N., Kosinski, M., Stillwell, D. J., \& Rust, J. (2014). Can well-being be measured using Facebook status updates? Validation of Facebook's gross national happiness index. Social Indicators Research, 115(1), 483-491.

Wang, Z., \& Tchernev, J. M. (2012). The "myth" of media multitasking: Reciprocal dynamics of media multitasking, personal needs, and gratifications. Journal of Communication, $62(3), 493-513$.

We Are Social. (2014). Social, digital \& mobile worldwide in 2014. Retrieved from http:// wearesocial.net/blog/2014/01/social-digital-mobile-worldwide-2014/

Weston, R., \& Gore, P.A. (2006). A brief guide to structural equation modeling. The Counseling Psychologist, 34(5), 719-751.

Yakushev, A., \& Mityagin, S. (2014). Social Networks mining for analysis and modeling drugs usage. Procedia Computer Science, 29, 2462-2471.

Yavuz, S. (2005). Developing a technology attitude scale for pre-service chemistry teachers. The Turkish Online Journal of Educational Technology-TOJET, 4(1), 17-25.

Yuan, E. (2011). News consumption across multiple media platforms. Information, Communication \& Society, 14(7), 998-1016.

Zhong, B., Hardin, M., \& Sun, T. (2011). Less effortful thinking leads to more social networking? The associations between the use of social network sites and personality traits. Computers in Human Behavior, 27(3), 1265-1271. 
